\title{
Application of Laws of PRC Concerning Air Transport Lawsuits: What Should We Do in the Future?
}

\author{
Lizhi Wang \\ Law Faculty, Civil Aviation University of China, Tianjin, China \\ Email: Lizhi-wang@163.com
}

Received 1 April 2015; accepted 5 June 2015; published 10 June 2015

Copyright ( 2015 by author and Scientific Research Publishing Inc.

This work is licensed under the Creative Commons Attribution International License (CC BY).

http://creativecommons.org/licenses/by/4.0/

(c) (i) Open Access

\begin{abstract}
It is found that some of the conflicts among Chinese domestic private laws relating to carriage of passengers by air may be settled according to the law application rules and while some may not. The author also observes the roles played by the legislative body of China on the conflicts among domestic private laws. This paper concludes that the issues on the application of laws will be a long-term puzzle for Chinese Lawyers. This paper proposes to revise the laws, especially the Civil Aviation Law forthwith.
\end{abstract}

Keywords

Application of Laws, Air Carrier's Liability, Conflicts, Air Transport Lawsuits

\section{Introduction}

The air carrier's liability rules may be construed in two different ways from the perspective of substantive law. On one hand, the rules set the bottom limit of the carrier's liabilities, and any deduction of the liabilities by carrier may be deemed as a breach of law. On the other hand, the said rules establish the minimum rights for protection of air passengers, under which the passengers may be entitled to claim against the carrier. Notwithstanding the provisions of laws of PRC in force concerned, the practices in protecting passengers' rights and interests always result in judicial puzzles. These difficulties are due to discrepancies and controversies on the scope of the carrier's liabilities, on the doctrine of liability fixation, and on the amount of compensation provided for in related laws.

As far as the judicial puzzles are concerned, the laws regulating carrier's liabilities and their conflicts are the core of the whirlpool. 


\section{The Chinese Laws Concerning to Air Carrier's Liability and the Conflicts}

There are some laws governing the liabilities of air carrier in PRC, which include, but not limited to, the Act on General Civil Principles, promulgated in 1986 (hereinafter called “the General Principles”), the Contract Law 1999, the Tort Law 2009, the Act Concerning Protection of Customers’ Rights and Interests 1993 (hereinafter referred to as "the Customer Act”), and the Civil Aviation Law 1995, amended in 2009. All of the concerned provisions of the foregoing laws constitute China’s legal system on air carrier's liabilities, as well as the conventions China entered into.

\subsection{Conflicts between the General Principles and the Civil Aviation Law}

The General Principles provided the basic norm which the subjects should obey in civil activities. Therefore, a carrier should be liable for the losses of or damages to passengers thereunder if the General Principles are violated. However, there are conflicts between the General Principles and the Civil Aviation Law in the aspects of basic rules, which render the probability of application of the said laws in a certain case lower. For instance, compensation rule of the General Principles is set up to recover the rights and interests to the extent of the state which it was. Hence there is no limitation of liability for the infringer or defaulter, who must compensate the claimant pursuant to the actual losses of victim. On the contrary, the Civil Aviation Law provides the carrier may limit his liability to a certain amount under certain criteria and may refuse to compensate since the claim amount exceeds the limit. As for the doctrine of liability fixation, the General Principles provides that an infringer or defaulter's liabilities shall be fixed in accordance with the fault thereof, supplemented by the principle for presumption of fault of the same. While the Civil Aviation Law provides that air carrier shall be liable for the personal injure and/or losses of passenger's luggage caused by accidents during passenger's embarking and/or disembarking and/or aboard aircraft on the basis of principle for presumption of fault of the carrier. And where tort law and contract law compete to be applied, the General Principles has no restriction to the option of plaintiff. However, the Civil Aviation Law regulates the compensation conditions and limitation of liabilities shall be applied even if the claim is based on tort law.

\subsection{Conflicts between the Customer Act and the Civil Aviation Law}

For the purpose of application of the Customer Act, the transport service should be accepted by passengers who travel for living needs as is provided for in Article 2 thereof. And in this case, passengers have right to learn the truth, have right to be safe in transit, have right to option, and have right to even bargain, etc., which shall be guaranteed by air carrier. However, the staff and workers of legal entities and agencies or other organizations may not share the passengers' interests protected by the Customer Act when they travel on business. Everyone present at this symposium today, including myself, are not customers even though we bought air tickets because we are on business trip! That is ridiculous! So Chinese dislike being on business trips because the Customer Act makes it difficult for them to do so! In my opinion, the customer shall be defined as those who buys or has bought goods and services, regardless of the reason for purchase of goods or acceptance of services. There are no provisions pertaining to the rights mentioned above in the Civil Aviation Law. The right to know, for an instance, is not a passenger's written right thereunder. Thus, the passengers on board the same aircraft may have different rights because some of them belong to consumer groups specified in the Customer Act. Others who are on a business trip may not be entitled the right to know the real reason for delays due to the Customer Law. Of course we may not hope to find legal basis of right to learn the reason for delay for those who are on official travel in accordance with the Civil Aviation Law. That's unreasonable and unfair!

\subsection{Conflicts between the Contract Law and the Civil Aviation Law}

The carrier's general obligations includes, but not limited, as follows under the Contract Law: obligation of acceptance of reasonable transport offer [1], obligation of arrival as schedule [2], obligation of non-deviation [3], obligation of guaranteeing of passengers' right to know [4], obligation of non-deleveling the standards of services [5], and the obligation of saving lives [6]. Speaking of the compensation liability, the Contract law institutes the principle of presumption of fault on personal injure and consigned baggage (as well as cargo) [7], and principle of fault on carry-on articles of passengers [8], and limitation of compensation amount [9] as well.

Some obligations as is provided for in the Contract Law are the same as obligations specified in the Civil 
Aviation Law, while some are different. Supposing that the losses of or damages to carry-on articles of a passenger, the air carrier should assume liability for the losses or damages thereto arising from an accident on the aircraft or during the passenger's embarking or disembarking the aircraft owing to the fault of the carrier under the Contract Law. For the Civil Aviation Law, it is not necessarily the case, because the rule to fix the liability of air carrier is to presume the carrier has fault(s) for the occurrence of the accident. So, the air carrier should compensate the passenger's loss unless otherwise satisfied the requirements of immunity of liabilities. That is to say, the carrier must prove that the losses of and/or damages to the carry-on articles of the passenger were resulted entirely from the nature, quality or defects of the articles itself so as to be free from the liability to compensate.

Another highlighted discrepancy between the Contract Law and the Civil Aviation Law is the limitations of liability. The limits specified in the Contract Law fall into four categories, which may be called an agreed limit, customary limit, market value of luggage, and statutory limit respectively [10]. What's more, the limit decided in according to the market value of luggage should not be deemed as limiting the compensation because it means compensating actual losses. And there is no provision on the number with which the parties concerned may agree. The Civil Aviation Law provides agreed limit and statutory limit of liabilities and the former can be enforced on condition that it is higher than the latter.

\subsection{Conflicts between the Tort Law and the Civil Aviation Law}

The conflicts between the Tort Law and the Civil Aviation Law mainly focus on controversies of liability system as is provided for in the two laws. For the principle of liability fixation, notwithstanding the provisions on principles of fault and presumption of fault as is specified in the Tort Law and the Civil Aviation Law, the types of faults and the power of causation which caused the losses of passengers are not the same. The article 127 of Civil Aviation Law reads: "If the carrier proves that the damage was caused or contributed to by the fault of the person claiming compensation, the carrier shall be wholly or partly exonerated from its liability to the claimant to the extent that such fault caused or contributed to the damage." [11]. This article may always be interpreted as the exemption clause of carrier's liabilities. It is the chain of causation between the faults and damages that decides the results of lawsuits. While the fault nature, which caused by carrier's negligence, omission, or intention to the damages, is not taken into considerations in deciding the compensation case pursuant to the Civil Aviation Law. As regards the exemption of liability, the judge hearing the case may wholly exonerated from the carrier's liability to the claimant provided that the damages are totally caused on the part of faults of the carrier. Where the damages are partly caused by the fault of the carrier, the deduction proportion of the compensation amount may be decided at the judge's discretion. Notwithstanding the forgoing considerations, the responsibilities of taking care of the wounded passengers may not be exonerated.

The deduction of liability which resulted from partly faults of the claimant is also provided by the Article 26 of the Tort Law. However, the article 27 provides that the carrier is not liable to the claimant having intention to cause the damages. We can hence understand that the faults provided for in article 26 means negligence only. If the carrier desires to be completely free from any compensation, the carrier must bear the burden of proof of the passenger's intention, and the negligence or omission thereof may not be a legal defense excuse.

The third party shall be liable for the damages caused by his own faults under the Tort Law [12]. However, the air carrier shall be liable for the injures of passengers, the losses of or damages to the carry-on articles and consigned luggage rising from an accident on the aircraft, or during passenger's embarking or disembarking the aircraft [13] even though the damages were caused by the third party. Of course, the carrier is entitled to recover losses from the third party, which means the tortfeasor may not be free from the liability. However, the victim has the right to claim compensation to carrier directly. There are no substantive discrepancies between the said provisions from the perspective of liability bearing. The difference originates from fundamental theories thereof. The Tort Law is made on the basis of tortfeasor's own responsibility theory and the Civil Aviation Law on the privity of contract. Therefore, if the victim chooses to bring a lawsuit based on default of contract or breach thereof after an aircraft accident, which is caused on the part of the third party, the right person he may sue is the carrier. The infringer, viz the third party, may be sued in tort claim action.

In the aspect of compensation amount, the Tort Law permits the claimant to be paid the same compensation as in a fatal accident [14]. The limitations of liability set up for international air passengers in Civil Aviation Law are different from that for domestic air passengers, which may lead to different results as to the compensation 
money.

\subsection{Conflicts among the General Laws}

The Contract Law and the Tort Law are general laws for the rules of common air carriage provided for in the Civil Aviation Law at the claimant's option of action cause. Therefore, the conflicts between the Contract Law and the Tort Law have significant influence upon the judgment of air carriage cases. According to the Tort Law, for example, the carrier is not liable for the damages caused by force majeure [15]. While the carrier is not liable for the damages to consigned luggage caused by force majeure [16] and shall be liable for the body injures or losses of or damages to the luggage so caused where delay occurs under the Contract Law [17]. Any legal action for damages arising from air transport can be brought on only in accordance with the conditions and limitations of liability for damages specified in the Civil Aviation Law irrespective of whatever grounds (actio ex contractu or actio ex delicto) on which the legal action is brought [18]. Nevertheless being liable or not does not mean being classified into the categories of conditions and limitations of liability. The said rules may not eliminate the different judgments made in accordance with the Contract Law and the Tort Law respectively.

Another example of conflicts between the general laws often discussed is the compensatory damages specified in the Contract Law or the punitive damages in the Customer Law. For passengers who travel for living needs, they are protected by both of the said laws. The puzzle thereupon emerges and the judge must choose to apply the compensatory damages or the punitive damages in actio doli.

\section{General Application Rules of Laws Concerning Air Carriers' Liability}

The conflicts between the Civil Aviation Law and the General Principles, the Contract Law, the Consumer Act, the Tort Law respectively fall into category of conflicts arising out of the application of special law (ius singular) and general law (ius commune). There is an application rule of laws in Roman law which says lex specialist derogat legi generali [19]. The provisions relating to the common air transport as are provided in the Civil Aviation Law are special rules to the corresponding legal systems set out in the General Principles, the Contract Law, the Consumer Act, and the Tort Law respectively. Therefore, the Civil Aviation Law shall prevail where the aforesaid laws compete to govern a same case. However, the special law on aviation transport has being played a weak role in China. Taking the liability system in consideration, we may find that the system was designed too simple to regulate the special aspect of carriage of passengers by air. For example: the Civil Aviation Law provides that the carrier shall be liable for delay in air transport without the definition of delay, so the meaning of delay shall be interpreted under the Contract Law. However, the tarmac delay is not part of the meaning thereof under the Contract Law. The point is how shall we deal with the tarmac delay disputes according to the Civil Aviation Law? Actually we have no rules on this. Another example is we have no answer for the exemption and limitation of liability where the aircraft is unairworthy, nor have rules on the discrepancy between the airworthiness certificate and actual unairworthiness at the time the certificate is valid. It is that the Civil Aviation Law lays less emphasis on such special issues pertaining to air transport, as cannot be found in general laws as well, and leads to passive conflicts with no provisions for such problems.

As for the conflicts among the general laws, it is necessary to deal with each case on its own merits. With regard to the application scopes of different laws, whatever the differences are, the judgment must be subject to the indemnity conditions and limitation of liability specified in the Civil Aviation Law. Where two different laws compete to regulate a case, such as the conflicts between the compensatory damages specified in the Contract Law and the punitive damages in the Customer Law, the case shall be decided under the values and spirits of laws. That is to say, if passengers' bodies injures or damages to luggage caused on the part of carrier's actual fraud, the punitive damage rules shall be applied. Otherwise, the compensatory damage rules shall be applied under the value standard of equity and justice. As regards inter-temporal conflicts, if the new law and the old one are in force concurrently, the principle of new law prevailing over the old shall go for the case.

As the fundamental private law in China, due to the special backgrounds in 1980's, the General Principles has many different provisions to the other private laws, which was based on the situations and social developments 10 to 20 years later. However, the newer private laws are special laws for the General Principles. Conflicts may be settled according to the principle of special law prevailing over the general one. In other words, the General Principles applies at the end of the list of laws when it comes to compensatory problems. The elementary provisions concerning civil activities, such as the fundamental principles, the subject systems, the systems of civil act 
and so on, provided for in the General Principles may be applied when there is no such provisions in the Civil Aviation Law.

\section{Some Special Points to Be Settled}

In spite of the law application rules, there are hard nuts to cut for the application of laws relating to air carrier's liability. Hereby three points will be discussed as follows:

\subsection{How to Settle the Conflicts between or among the Law Application Rules?}

As we all know, the Civil Aviation Law was enacted on October 30, 1995. The Contract Law was promulgated on March 15th, 1999. The latter shall prevail where the rules specified in the said laws conflict pursuant to the principle of new law prevailing over the old. However, the former shall be applied, vice versa, according to the principle of special law prevailing over the general one. Hence, the two principles drive the lawyers and judges crazy in a situation in which the Civil Aviation Law and the Contract Law compete to be applied. What is the suitable approach to settle such problem?

The Article 85 of Law of the People's Republic of China on Legislation reads, "When the new general provisions and the old special provisions of different laws on the same matter are inconsistent and it could not decide which is applicable, the Standing Committee of the National People's Congress makes a ruling thereon.” However, the Committee has not made any rules on the inconsistency since the Contract Law went into effect in 1999. Therefore, how to deal with the said conflicts is the main task for China legislative body henceforth. And I herewith strongly recommend that the Standing Committee of the National People's Congress ("the Committee") should interpret the conflicts among the laws of PRC_-including the Civil Aviation Law and the Contract Law.

Another option for us is to amend the Civil Aviation Law where the Committee does not make interpretation rules for the conflicts, which will be definitely not happen to some extent at least in a few years. Let us take the fixation principle of liability for articles carry-on as an illustration for the necessity for revising the Civil Aviation Law. It is well known that the Contract Law provides that the carrier shall be liable for the damages to the articles carry-on contributed to his faults, which is so called the principle of fault. And the Civil Aviation Law directs the carrier to indemnify the passenger's damages pertaining to the articles carry-on, with the exception that the carrier can prove that the passenger's faults resulted in the damages, which is so called the Principle of Presumption of Fault. I don't think it is a proper way to settle the application problem by introducing law application rules to decide which law shall be prevail. The Montreal Convention 1999, ratified by China in 1 June, 2005, provides as the same provisions as that in the Contract Law relating to carrier's liability for the damages to the articles carry-on. China shall revise the Civil Aviation Law so as to consist with the obligation arising out of the convention. What's more, the carry-on articles were charged by passengers themselves. Therefore, it is hard to justify its legitimacy assuming that the carrier is at fault to the damages to the articles. It is strongly recommended that the Civil Aviation Law be revised under the Contract Law concerning the fixation principle of liability for articles carry-on.

Speaking of the limitation of liability, China's laws created a different system on domestic carriage by air from that on international carriage by air. After the Montreal Convention 1999 was enforced for China, China has three different limitation of liability to carry-on articles. This is not in conformity with the spirit of law and equality requirements that also leads to confusion of law application. Therefore, such odd system must be replaced by uniform liability limitation system in the future.

\subsection{Issues on Law Application Concerning actio ex delicto}

The damages and injuries suffered by passengers may be claimed under the contract of carriage of passengers by air. However, it is the result of weighing situation and the ways to sue the carrier that the plaintiff brings a lawsuit based on infringement, or default, or breach of contract. Where the passenger was carried with the carrier's consent without ticket, the passenger is apt to understand that there is no contract between the carrier and himself/herself and files against the carrier for tort if he/she suffers injuries or damages while in transit. Sometimes, the passenger institute an actio ex delicto just because the Tort Law's provisions is better for protecting his/her rights and interests, though he/she understands that there is contract with the carrier. From the perspective of nature of the air losses and damages, "it is obviously the carrier breached the contract if the aim of the contract 
is hard to realized [20]" due to air accident since there is a contract of carriage of passenger by air between the carrier and passenger. The Contract Law and Civil Aviation Law may govern the case. In the meanwhile, the injures of passengers' bodies, the losses of or damages to luggage caused by accidents may also be characterized as infringement of personal rights over bodies or real rights, therefore, the Tort Law may be applied. The concurrent liability leads towards the puzzle of option of the Tort Law and the Contract Law. According to article 122 of the Contract Law, where a party's breach harmed the personal or property interests of the other party, the aggrieved party is entitled to elect to hold the party in question being liable for breach of contract in accordance herewith, or hold the party being liable for tort in accordance with any other relevant law [21].

Therefore, theoretically, where the parties choose to bring actio ex contractu, the laws on contract and air transport shall be governing laws; and where the parties choose to bring actio ex delicto, the laws for torts shall be applied accordingly and the Civil Aviation Law may not be applied since the provisions are designed for contract issues. However, it is not necessarily the case. The article 131 of the Civil Aviation Law provides that any legal action for damages arising from air transport can only be brought subject to the conditions and such limits of liability as are set out in this Convention without prejudice to the question as to who are the persons who have the right to bring suit and what are their respective rights [22]. It shows that the basis of claim has no influence on the application of the provisions in Civil Aviation Law on the limits of liability and conditions to sue, which include without limitation of the provisions on or about the conditions the carrier being liable for, the grounds of defense, burden of proof, and the conditions of depriving of right to limit liability. Notwithstanding the aforesaid provisions, whether the Civil Aviation Law may be applied or not as to who are the persons who have the right to bring suit and what are their respective rights and how to be recovered should be decided pursuant to the situation.

Therefore, in case that the passenger brings an action of contract, the Civil Aviation Law, the Contract Law and the General Principles may be applied. Where there are conflicts among the said laws, they shall be applied according to the order list above which are conformity with the law application rules-the principle of special law prevailing over the general one. However, the conflicts between the Contract Law and the Civil Aviation Law shall be settled according to the ways aforesaid.

In the event that an action of tort was brought, the Civil Aviation Law, the Tort Law and the General Principles may be applied concurrently. However, the Tort Law shall be applied subject to article 131 of the Civil Aviation Law. Where there are conflicts among the said laws, they shall be applied according to the order as follows:

1) Fixation principle of liability clauses of Civil Aviation Law.

2) Liability clauses of Civil Aviation Law.

3) Clauses of Civil Aviation Law on grounds of defense.

4) Clauses of Civil Aviation Law on burden of proof.

5) Clauses of Civil Aviation Law on limitation of liability.

6) Clauses of the Civil Aviation Law on conditions of depriving of right to limit liability.

7) Tort Law.

8) General Principles.

The conflicts between Tort Law and Civil Aviation Law shall nevertheless be settled as the way proposed to the conflict puzzles resulting from Contract Law.

\subsection{The Problem on the Application of Article 71 of the Tort Law}

Article 71 of the Tort Law set out the principle of presumption of fault of the operator of aircraft similar to that of the Civil Aviation Law, which reads: "Where a civil aircraft causes any harm to another person, the operator of the civil aircraft shall assume the tort liability unless the operator can prove that the harm is caused by the victim intentionally." But for the cause of the accident, there are some discrepancies between the Tort Law and the Civil Aviation Law. The latter requires the carrier, if the carrier wants to be free from the liability, it must prove that the harm was caused by the victim's bad health, the nature, quality or defects of the luggage, without the needs of proving the subjective mental status. Tort Law set out the subjective criterion and the Civil Aviation Law instituted the objective one.

The article is set out in Chapter 9 of Tort Law, which regulates the liability to highly dangerous activities of the operators, owners, occupiers or managers. Such a lay-out shows that those who operate own, occupies, or 
manages the activities have no relationship with the victims prior to infringement affairs happening. And from the perspective of the wording of Art, 71 of Tort Law, the subject word is civil aircraft, which expressly indicates that the article is set out for governing the tort disputes caused by civil aircraft instead of carriage by air.

Therefore, the article 71 of Tort Law may not be applied to judge the liability pertaining to the air carriage. The article provides for the liability for the harm caused on the part of infringement of civil aircraft to the properties and persons outside thereof who are not passengers. As discussed above, the principle of liability fixation belongs to the conditions prescribed in article 131 of Civil Aviation Law, while the article 71 of Tort Law does not. Therefore, the law that applies shall be the Civil Aviation Law.

\section{Conclusion: What Shall We Do in the Future?}

It is found that there are conflicts among domestic private laws relating to carriage of passengers by air. Some of the conflicts may be settled according to the law application rules and some may not.

And it is also found that the legislative body of China has not played its roles in making rules very well. Therefore, the issues on application of laws will be a long-term puzzle for Chinese Lawyers.

Chinese lawyers and scholars have realized the awkward situation, and so has the CAAC. Therefore, we are endeavoring to push on with the revision of relative laws.

It is strongly recommended to amend concerning provisions in the Civil Aviation Law, including, but not limited to:

1) To abolish the different limitations of liability of air carrier;

2) To set out the special system which the air transport needed, such as the definition of delay, tarmac delay, and the civil liability system on unairworthiness;

3) To amend the limits of liability so as to comply with the Montreal Convention 1999;

4) To revise the principle of liability fixation specified in the Civil Aviation Law 2009;

5) The application order of the laws competing to be applied to aviation lawsuit;

6) To set out the application conditions of conflicting laws.

Of course the other laws, for an instance, the Customer Act shall be revised pertaining to the scope of application so as to protect the rights and interests of passengers on business trips.

\section{References}

[1] Article 289 of the Contract Law.

[2] Articles 290 and 299 of the Contract Law.

[3] Article 291 of the Contract Law.

[4] Article 298 of the Contract Law.

[5] Article 300 of the Contract Law.

[6] Article 301 of the Contract Law.

[7] Articles 302 and 311 of the Contract Law.

[8] Paragraph 1, Article 303 of the Contract Law.

[9] Articles 312 of the Contract Law.

[10] Articles 61 of the Contract Law.

[11] Article 127 of the Civil Aviation Law.

[12] Article 28 of the Tort Law.

[13] Articles 124 and 125 of the Civil Aviation Law.

[14] Article 17 of the Tort Law, Which Reads: "Where the Same Tort Causes the Deaths of Several Persons, a Uniform Amount of Death Compensation May Be Determined.”

[15] Article 29 of the Tort Law

[16] Paragraph 2, Articles 303 and 311 of the Contract Law.

[17] Article 117 of the Contract Law.

[18] Article 131of the Civil Aviation Law.

[19] The Principle Was First Affirmed by the Article 83 of the Legislation Act. 
[20] Minyi, T. and Yu, C. (2004) On International Private Law. Law Press, Beijing, 111. In This Book, the Author Believes That the International Conventions on Air Carriers’ Liability Belong to Private Law on Theory. So the Meaning of International Private Law Is Different from That of Private International Law, Which Regulates the Conflicts Issues among Different Countries' Laws and Determines Which Country’s Law Shall Be Applied to a Case.

[21] Article 122 of the Contract Law.

[22] Article 24 of Warsaw Convention, 1929 and Article 29 of Montreal Convention1999. 